\title{
Effect of Breathing Nostril and Back Massage On Blood Pressure Reduction in Hypertension Patients in The Working Area of Hospital Pertamina Jaya
}

\author{
Sofyan, Rohman Azzam, Mustikasari \\ Universitas Muhammadiyah Jakarta, Indonesia \\ *sofyanrusliladina@gmail.com
}

\begin{abstract}
Hypertension is an abnormal increase in blood pressure in the arteries continuously for more than one period. Handling of hypertension can be done with secondary prevention such as nostril breathing and back massage techniques. This study aims to determine the effect of nostril breathing and back massage on lowering blood pressure in hypertension in the working area of Pertamina Jaya Hospital. The research design used was a quantitative research design with the research method Quasy Experiment pretest and posttest with the control group. The total sample was 76 respondents who experienced hypertension. The nostril breathing and back massage intervention group consisted of 38 respondents and the control group 38. Blood pressure was measured using a sphygmomanometer and a stethoscope. The statistical test used is the dependent $t$-test and the results obtained are systolic 0.000 and p-value diastolic 0.000 . Based on the results of the analysis, this nonpharmacological therapy affects reducing blood pressure.
\end{abstract}

Keywords: Nostril Breathing, Back Massage, Hypertension 


\section{STRADA Jurnal Ilmiah Kesehatan}

DOI: $10.30994 /$ sjik.v9i2.484

ISSN: 2252-3847 (print); 2614-350X (online)

Vol.9 No.2 November 2020 Page.1396-1402

\section{BACKGROUND}

Hypertension or high blood pressure is defined as an increase in blood pressure continuously so that it exceeds normal limits. Hypertension is often dubbed the Silent Killer because it is a deadly disease without symptoms and that is the hallmark of cardiovascular disease (Kalaivani, Kumari, \& Pal, 2019). According to the World Health Organization (WHO, 2016), the disease that causes death in the first place is Cardiovascular Diseases (CVD) (Damasceno, 2016).

World Health Organization (WHO) 2016 in the section in the Global Status Report On Non-Communicable Disease, the prevalence of high blood pressure in 2018 in adults aged 18 years, is around 24\% (Damasceno, 2016). This disease is also responsible for $40 \%$ of deaths from heart disease. Globally, hypertension is also one of the most common noncommunicable diseases in the world (57.6\%) (Ansar, Indra, \& Apriani, 2019).

The Ministry of Health of the Republic of Indonesia, through the Riskesdas 2018 Report, stated that the prevalence of hypertension based on the measurement results for people aged $\geq 18$ years was $34.1 \%$, the highest was in South Kalimantan (44.1\%), while the lowest was in Papua (22.2\%). The estimated number of hypertension cases in Indonesia is $63,309,620$ people, while the death rate in Indonesia due to hypertension is 427,218 deaths (Anitasari, 2019). The Ministry of Health 2018 stated that the prevalence of hypertension based on measurement results for residents aged $\geq 18$ years by province, found that DKI Jakarta was in the top 10 with a percentage of $33.43 \%$ (Siswanto, 2018).

Relaxation is an intervention that can be done in any anti-hypertensive therapy by reducing the symptom stress that a person feels in facing various situations, reducing heart rate and blood pressure, and stabilizing muscle tension. (Potter, Perry, 2010). There are many types of relaxation techniques, including nostrils breathing relaxation techniques and these techniques are successful in lowering blood pressure (Telles, Sharma, \& Balkrishna, 2014). based on research, the back massage technique is quite effective in controlling the stress response, and in a relaxed state, it will have a vasodilating effect on blood vessels, causing blood pressure to fall and slowly return to normal (Mohebbi, Moghadasi, Homayouni, \& Nikou, 2014). Alternative therapies such as nostril breathing and back massage can be an option to lower blood pressure. Generally, these two interventions based on previous research can lower blood pressure (Shinta, Winaya, \& Tianing, 2015), but there are no studies that combine these two non-pharmacological therapies.

\section{METHODS}

The research design used was a quantitative research design with the research method Quasy Experiment pretest and posttest with the control group. The total sample was 76 respondents who experienced hypertension. The nostril breathing and back massage intervention group consisted of 38 respondents and the control group 38.

\section{RESULTS}

\section{Univariate Analysis}

\section{a. Respondent characteristics}

Table 1.1 Frequency distribution of respondents based on age in respondents who have hypertension at Pertamina Jaya Hospital

\begin{tabular}{lccccc}
\hline \multicolumn{1}{c}{ Age } & Mean & Median & SD & \multicolumn{2}{c}{ CI 95\% } \\
\cline { 5 - 6 } & & & & MIN & MAX \\
\hline intervention group & 47,21 & 48,00 & 5,458 & 34 & 55 \\
\hline Control group & 44,13 & 44,50 & 6,921 & 26 & 60 \\
\hline
\end{tabular}




\section{STRADA Jurnal Ilmiah Kesehatan}

DOI: $10.30994 /$ sjik.v9i2.484

ISSN: 2252-3847 (print); 2614-350X (online)

Vol.9 No.2 November 2020 Page.1396-1402

From table 1.1, it is obtained data that the age of the respondents who experienced hypertension in the intervention group with a mean value of $42 \%$, median $48 \%$, SD 5.458, 95\% CI value, $24 \%$ MIN, 55\% MAX, while in the control group the mean result was 44.13, median 44.50. SD 6,921 CI 95\% MIN 26\% and MAX $60 \%$.

\section{b. Blood pressure characteristics}

Table 1.2 Frequency distribution of blood pressure respondents to respondents with hypertension at Pertamina Jaya Hospital

\begin{tabular}{cccccccc}
\hline \multirow{2}{*}{ Group } & \multirow{2}{*}{$\begin{array}{c}\text { Measurement } \\
\text { time }\end{array}$} & \multicolumn{3}{c}{ Systolic blood pressure } & \multicolumn{3}{c}{ Diastolic blood pressure } \\
\cline { 2 - 8 } intervention group & N & Mean & SD & $\mathrm{N}$ & Mean & SD \\
\cline { 2 - 8 } & pre & 38 & 156,03 & 11,95 & 38 & 84,53 & 5,90 \\
\hline Control group & post & 38 & 136,00 & 9,59 & 38 & 80,18 & 5,19 \\
\cline { 2 - 8 } & pre & 38 & 155,58 & 6,25 & 38 & 81,95 & 5,45 \\
\hline
\end{tabular}

Based on the table above 1.2, the results of pre-intervention for systolic blood pressure before intervention are $153.03 \mathrm{mmHg}$ with a standard deviation of 11.95 , diastolic blood pressure 85.58 with a standard deviation of 4.89 . Post-intervention was carried out with a systolic blood pressure value of $135.18 \mathrm{mmHg}$ with a standard deviation of 8.46 , a diastolic blood pressure value of $83.34 \mathrm{mmHg}$ with a standard deviation of 5.60.

\section{Equality test}

Table 2.1 The Difference in Respondents' Blood Pressure Between the Intervention Group and the Control Group at Pertamina Jaya Hospital

\begin{tabular}{|c|c|c|c|c|c|c|}
\hline \multirow[t]{2}{*}{ Group } & \multirow{2}{*}{$\begin{array}{c}\text { Blood } \\
\text { Pressure }\end{array}$} & \multirow{2}{*}{$\begin{array}{c}\text { Pre } \\
\text { Mean }\end{array}$} & \multicolumn{3}{|c|}{ Post } & \multirow[t]{2}{*}{$P$ value } \\
\hline & & & SD & Mean & SD & \\
\hline \multirow{2}{*}{$\begin{array}{l}\text { Intervention } \\
\text { group } \\
\end{array}$} & Systolic & 156,03 & 11,95 & 136,00 & 9,56 & 0,881 \\
\hline & Diastolic & 84,53 & 5,90 & 80,18 & 5,19 & 0,607 \\
\hline \multirow{2}{*}{$\begin{array}{l}\text { Control } \\
\text { group }\end{array}$} & Systolic & 155,58 & 6,25 & 155,37 & 6,91 & 0,275 \\
\hline & Diastolic & 81,95 & 5,45 & 82,84 & 5,47 & 0,336 \\
\hline
\end{tabular}

Based on table 2.1, the mean value of systolic blood pressure in the intervention group was 156.03 with a standard deviation of 11.95 with a p-value while the diastolic blood pressure value was 84.53 . P-value 0.881 , the result of systolic blood pressure in the control group is 155.58 with a standard deviation value of 6.25 . While the pressure value.

\section{Bivariate analysis}

a. Changes in blood pressure drop before and after the intervention of Nostril Breathing and Back Massage

Table 3.1 Changes in Blood Pressure of Respondents Before and After Intervention with hypertension at Pertamina Jaya Hospital

\begin{tabular}{|c|c|c|c|c|c|c|c|}
\hline \multirow{2}{*}{$\begin{array}{c}\text { Blood } \\
\text { Pressure }\end{array}$} & \multirow{2}{*}{$\begin{array}{l}\text { Measurement } \\
\text { time }\end{array}$} & \multicolumn{3}{|c|}{ Intervention } & \multicolumn{2}{|c|}{ CI $95 \%$} & \multirow[t]{2}{*}{ P-Value } \\
\hline & & Mean & SD & SE & MIN & MAX & \\
\hline \multirow[t]{2}{*}{ Systolic } & Pre & 156,03 & 11,95 & 1,940 & 140 & 188 & 0,00 \\
\hline & Post & 136,00 & 9,56 & 1,374 & 120 & 160 & \\
\hline \multirow[t]{2}{*}{ Diastolic } & Pre & 84,53 & 5,90 & 1,089 & 70 & 110 & 0,032 \\
\hline & Post & 80,18 & 5,19 & 0,893 & 70 & 90 & \\
\hline
\end{tabular}




\section{STRADA Jurnal Ilmiah Kesehatan}

DOI: $10.30994 /$ sjik.v9i2.484

ISSN: 2252-3847 (print); 2614-350X (online)

Vol.9 No.2 November 2020 Page.1396-1402

Based on the results of table 5.6 analysis, it can be seen that the average systolic blood pressure before the intervention was $156.03 \mathrm{mmHg}$ with a standard deviation of 11.95, SE 1.940 CI 95\% MIN 140 MAX 188 and after intervention $136.00 \mathrm{mmHg}$ SD 9, 56, SE 1.374 MIN 140, MAX 160 with, while the diastolic blood pressure before the intervention was carried out 84.53 with a standard deviation of 5.90 after the intervention action obtained diastolic results of 80.18 with a standard deviation of 5.19, SE 0.896, MIN 70 and MAX 90. With a p-value of 0.000 and a diastolic blood pressure before the intervention of $84.53 \mathrm{mmHg}$ with a standard deviation of 5.90, after the intervention, the diastolic results were 80.18 with a standard deviation of 5.19 and a p-value of 0.002 .

Based on the results of the above analysis, before and after the intervention was carried out, it had a smaller value after the intervention, with a p-value of 0.000 for systolic and a p-value of diastolic after the intervention was 0.002. So it can be concluded that there is a significant decrease in blood pressure between the average systolic blood pressure and the $\mathrm{p}$-value of 0.000 and the diastolic $\mathrm{p}$-value of 0.002 (pvalue $<0.05$ ).

b. Changes in Differences in blood pressure reduction at post-intervention and post control

Table 3.2 Differences in post-intervention and control blood pressure reduction in the provision of Nostril Breathing and Back Massage interventions at Pertamina Jaya Hospital

\begin{tabular}{cccccccc} 
Blood & Measurement & \multicolumn{3}{c}{ Intervention } & \multicolumn{2}{c}{ CI 95\% } & P-Value \\
Pressure & time & Mean & SD & SE & MIN & MAX & \\
systolic & Pre & 156,03 & 11,95 & 1,940 & 140 & 188 & 0,00 \\
& Post & 136,00 & 9,56 & 1,374 & 120 & 160 & \\
\hline Diastolic & Pre & 84,53 & 5,90 & 1,089 & 70 & 110 & 0,015 \\
& Post & 80,18 & 5,19 & 0,893 & 70 & 90 &
\end{tabular}

Based on table 3.2 above, the results of the analysis show that there is a difference in the decrease in blood pressure in the intervention and control groups which is marked by the mean value of systolic blood pressure before the action 156.03, SD 11.95, SE 1.940 MIN 140 MAX 188 and after the action 136.00 SD 9, 56, SE 1.374 MIN 70 MAX 110 results of p-value 0.00 on systolic blood pressure and mean diastolic blood pressure before and after action 84.53 SD 5.90 SE 1.089 MIN 70 MAX 110 after action mean value 80.18, SD 5.19 SE 0.893 MIN 70 MAX 90 at p-value 0.015 on diastolic blood pressure, it indicates a significant difference in reduction.

\section{DISCUSSION}

The results showed that of the 76 respondents with hypertension, most of them were $>47$ years old. Conceptually, the age factor is one risk factor that cannot be changed. Increasing age is one of the triggers for high blood pressure. This means that the older a person is, the higher the likelihood of experiencing hypertension. This happens because blood vessels tend to harden in old age. PERHI (2019) states that someone who is over 45 years old. From the results of this study, the respondents' age was included in the middle age category.

All forms of cardiovascular disease increase in frequency concerning age and suggest that the aging process alters vascular function including changes in vascular endothelium. Endothelial changes include increased endothelial cell turnover and density, marked heterogeneity in endothelial cell size, and protrusion of cells into the lumen. 


\section{STRADA Jurnal Ilmiah Kesehatan}

DOI: $10.30994 /$ sjik.v9i2.484

ISSN: 2252-3847 (print); 2614-350X (online)

Vol.9 No.2 November 2020 Page.1396-1402

Changes are also associated with changes in function and intima thickening with the accumulation of leukocytes, vascular smooth muscle cells, and fibroblasts as well as deposition of the matrix (Sargowo, 2015).

Increasing age was also associated with a decrease in the number of nephrons. Research by Bin Mohd Arifin \& Weta, (2016).in 10 middle-aged people (35-59) with a history of hypertension, it was found that they had significantly fewer numbers of nephrons than the control group who had normal blood pressure.

Respondents in the study, both the intervention and control groups, were all male (100\%). The results of this study are in line with the research of Jarky, et al. (2005) in 860 respondents aged 21-70 years, the prevalence of hypertension in men was slightly higher $(6.4 \%)$ than in women $(6.1 \%)$. Research by Kusumawaty, Hidayat, \& Ginanjar, (2016)is in line with the results of a study of 131 respondents aged 50-60 years, more men who have hypertension than women.

This sex difference is related to differences in blood vessel tone mass and the possible protective effect of the female sex hormones, namely estrogen and progesterone. A similar study by Portaluppi, Pansini, Manfredini \& Mollica (1997) in a cross-sectional study on the effect of menopause status on blood pressure values, conducted on 2397 healthy women aged 35-65 years showed that postmenopausal women had higher blood pressure values than pre-menopausal patients. menopause and perimenopause.

The mean systolic and diastolic blood pressure before the intervention of Nostril Breathing and Back Massage, $156.03 \mathrm{mmHg}$ systolic, 84.5 diastolic value with p-value 0.000 , systolic blood pressure after nostrils breathing and back massage intervention 136.00 while the diastolic blood pressure is 80.18 with a p-value of 0.000 . From the results of this study, it can be seen that the intervention of nostril breathing and back massage in hypertensive patients can reduce systolic blood pressure by $20.3 \mathrm{mmHg}$ while diastolic blood pressure is $4.32 \mathrm{mmHg}$. This indicates that the intervention carried out on the respondent affects reducing blood pressure because the $\mathrm{p}$-value is $<0.05$.

This intervention affects because back massage can increase relaxation by reducing sympathetic nerve activity and increasing parasympathetic nerve activity resulting in vasodilation of the arteriolar diameter (Casar, 2004). The parasympathetic nervous system releases the neurotransmitter acetylcholine to inhibit sympathetic nerve activity by reducing cardiac muscle contractility, volume stroke, arteriolar and venous vasodilation, and then lowering blood pressure (Ardi \& Ekowatiningsih, 2018).

Based on the results of the table analysis that there is a difference in the decrease in blood pressure in the intervention and control groups which is indicated by the p-value of 0.00 on systolic blood pressure and the p-value of 0.01 on diastolic blood pressure, it indicates a significant difference in reduction.

This is because when one nostril dominates the contralateral hemisphere is activated. Breathing through the right nostril through the right spinal and associated with the left cerebral hemisphere causes increased stimulation of the sympathetic nervous system, breathing through the left nostril through the left spinal and is directly related to the right cerebral hemisphere which stimulates the work of the parasympathetic nerves so that the body will experience relaxation. Therefore, breathing with both nostrils or known as the nostril breathing technique can balance sympathetic and parasympathetic nerve activity, to stabilize blood pressure.

The p-value of 0.053 indicates that there is a relationship with systolic blood pressure because the p-value $<0.05$ and the diastolic p-value of 0.062 indicates there is no relationship because the $\mathrm{p}$-value is $<0.05$.This is in line with the research conducted by 


\section{STRADA Jurnal Ilmiah Kesehatan}

DOI: $10.30994 /$ sjik.v9i2.484

ISSN: 2252-3847 (print); 2614-350X (online)

Vol.9 No.2 November 2020 Page.1396-1402

Tisa Gusmiah (2014) that the correlation of age to decrease blood pressure based on age in the Aliyang health center, Pontianak city, from the data the p-value is 0.047 From the results of statistical tests, it was found that there was a significant relationship between age and changes in systolic blood pressure.

\section{CONCLUSION}

Based on the problems and objectives of the study and related to the analysis and discussion, in general, it can be concluded that there was a change in the decrease in blood pressure before and after the intervention of Nostril Breathing and Back Massage and there was also a difference in the decrease in blood pressure in the intervention and control groups after giving the intervention. Nostril Breathing and Back Massage in hypertensive patients.

\section{REFERENCES}

Anitasari. (2019). http://p2ptm.kemkes.go.id/kegiatan-p2ptm/pusat-/hari-hipertensi-dunia2019-know-your-number- kendalikan-tekanan-darahmu-dengan-cerdik KEMENKES RI 2019. 2019.

Ansar, J., Indra, D., \& Apriani, M. (2019). Determinan Kejadian Hipertensi Pada Pengunjung Posbindu Di Wilayah Kerja Puskesmas Ballaparang Kota Makassar. Nasional Ilmu Kesehatan, 1, 28-35.

Ardi, M., \& Ekowatiningsih, D. (2018). Efektivitas Slow Stroke Back Massage Dalam Meningkatkan Relaksasi Pasien Stroke Di Rumah Sakit Umum Daerah Kota Makassar. Media Kesehatan Politeknik Kesehatan Makassar, 12(1), 20. https://doi.org/10.32382/medkes.v12i1.32

Bin Mohd Arifin, M., \& Weta, I. (2016). Faktor-Faktor Yang Berhubungan Dengan Kejadian Hipertensi Pada Kelompok Lanjut Usia Di Wilayah Kerja Upt Puskesmas Petang I Kabupaten Badung Tahun 2016. E-Jurnal Medika Udayana, 5(7).

Damasceno, A. (2016). Noncommunicable Disease. In Heart of Africa: Clinical Profile of an Evolving Burden of Heart Disease in Africa. https://doi.org/10.1002/9781119097136.part5

Kalaivani, S., Kumari, M., \& Pal, and G. (2019). Alternate Nostril Breathing (Nadi Sodhan).

Kusumawaty, J., Hidayat, N., \& Ginanjar, E. (2016). Hubungan Jenis Kelamin dengan Intensitas Hipertensi pada Lansia di Wilayah Kerja Puskesmas Lakbok Kabupaten Ciamis. Jurnal Mutiara Medika, 16(2), 46-51.

Mohebbi, Z., Moghadasi, M., Homayouni, K., \& Nikou, M. H. (2014). The effect of back massage on blood pressure in the patients with primary hypertension in 2012-2013: a randomized clinical trial. International Journal of Community Based Nursing and Midwifery, 2(4), 251-258.

Sargowo, D. (2015). Disfungsi Endotel. Malang: Universitas Brawijaya Press (UB Press).

Shinta, A. . A., Winaya, I. M. N., \& Tianing, N. W. (2015). Pemberian Intervensi Slow Stroke Back Massage Menurunkan Tekanan Darah Pada Wanita Middle Age Dengan Kondisi Pre-Hypertension Di Banjar Batan Buah, Desa Kesiman, Kecamatan Denpasar Timur, Bali. Majalah Ilmiah Fisioterapi Indonesia, 2(1), 10.

Siswanto. (2018). Salam Sehat! Semoga fakta yang disajikan dalam buku ini , bermanfaat untuk perbaikan perencanaan pembangunan kesehatan. Laporan Riskesdas Nasional 2018.

Telles, S., Sharma, S. K. uma., \& Balkrishna, A. (2014). Blood pressure and heart rate 


\section{STRADA Jurnal Ilmiah Kesehatan}

DOI: $10.30994 /$ sjik.v9i2.484

ISSN: 2252-3847 (print); 2614-350X (online)

Vol.9 No.2 November 2020 Page.1396-1402

variability during yoga-based alternate nostril breathing practice and breath awareness. Medical Science Monitor Basic Research, 20, 184-193. https://doi.org/10.12659/MSMBR.892063 